\section{WINTER WREN}

P. Lawrence Becky, Bladworth

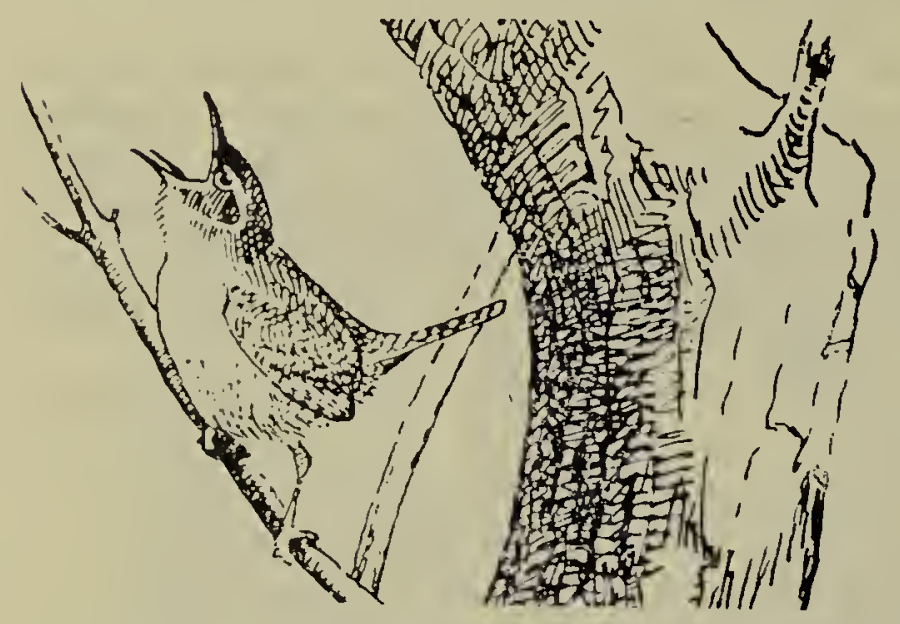

Yesterday, December 6, we had a rare visitor in our yard. And what a small bundle of feathers it was! I identified it (and I think correctly) as a Winter Wren. It was an unusual day, 36 degrees above at the time, with a clear sky and not even a slight breeze. Perhaps this Wren had overstayed its summer, being that the weather was so agreeable.

This littie Wren is quite a shy and retiring fellow-but not unsociable. I was able to get within ten feet of it while it remained safely in the depths of a clump of willows. Its nervous bobbing habit is what I first noticed. It is a compact little bird -with a stubby little tail.

This was my first encounter with the visitor. Taverner says it is an exceptionally fine songster-and that it nests in the woods of our northland.

\section{Yorkton Bird Notes}

On November 22, Cedar Waxwings were noted in the maples in Dr. Stuart Houston's front yard, whilst Bohemian Waxwings visited a crabapple tree in his back yard. Although Cedar Waxwings have twice remained in Yorkton until shortly after New Year's, and the Bohemians often arrive from the north in late October, this is the first time that both species have been observed in the same locality at the same time.

An intersting visitor from the coniferous belt was a little Brown-capped or Hudsonian Chickadee, constituting the second record for the Yorkton district. First seen on November 11, it was an intermittent visitor to the Houston's feeding tray and was banded on February 4th.

\section{THE BLUE HERON}

\section{Arthur Ward, Swift Current}

The most outsanding of many varieties of shore birds that stayed around here during the late summer was the Blue Heron. Three of these immature birds, finding conditions favorable for their nests, could be seen in the creek on the south side of the city well within the fringe of the residential quarters. They provided a pleasant and unusual sight.

Shallow waters, much more preferable than those of the much deeper bird sanctuary further south, provided good feeding grounds for the largest member of the Heron family. They are wary and suspicious, rising from the water with a squawk head drawn in with folded neck, and legs outstretched to seek a change upstream. Following them, I took a photograph of one standing upright in the water.

Whether one of the remaining Herons got safely away in migration is not known, but one was mercilessly shot and it is feared that the other may have suffered the same fate. On looking over the sanctuary, trespassing signs were observed to have been shot down and the posts studded with bullet holes.

It is becoming apparent that with the easy means of transportation at the disposal of the so-called sportsmen, the only place we will be able to see our vanishing species is behind the protective wires of the zco.

\section{A Note of Appreciation.}

\section{P. Robinson, Extension Dept., University of Saskatchewan}

Each issue of the "Blue Jay" appears to be a little better than the previous one. Four times a yearwhen the "Blue Jay" arrives-I stop thinking about the cares of the world for an hour or so and wander afield with the nature lovers who contribute to this excellent publication. In memory I am back again in my boyhood days among the birds, animals, flowers and trees of Saskatchewan's Parklands. I was raised west of Wadena. 